\title{
Pengembangan Model Latihan Passing Sepakbola Berbasis Sasaran Teman
}

\section{Development of a Goal-Based Peer-Based Soccer Passing Training Model}

\author{
Dian Pujianto*, Ari Sutisyana, Arwin, Yahya Eko Nopiyanto \\ Pendidikan Jasmani, Universitas Bengkulu, Jalan. WR Supratman, Kandang Limun, Bengkulu, 38371, \\ Indonesia \\ e-mail: dianpujianto@unib.ac.id, arisutisyana@unib.ac.id, arwin@unib.ac.id, \\ yahyaekonopiyanto@unib.ac.id
}

\begin{abstract}
Abstrak
Banyaknya kelemahan dalam pertandingan sepakbola terutama kelemahan dalam hal mengoper bola menjadi salah satu kunci kegegalan suatu tim dalam bertanding. Penelitian ini bertujuan mengembangkan bentuk latihan passing sepakbola. Penelitian ini menggunakan pendekatan penelitian pengembangan dengan sampel mahasiswa PJKR UNIB. Teknik analisis data yang digunakan menggunakan uj-t dengan perhitungan melalui SPSS versi 16. Hasil uji-t menunjukkan bahwa koefisien signifikasi sebesar 0,000, koefisien ini dibandingkan dengan taraf signifikasi 0,05. Berdasarkan perbandingan ternyata koefisien signifikasi hitung lebih kecil dari taraf signifikasi 0,05 , sehingga dapat disimpulkan program latihan passing memberikan pengaruh terhadap kemampuan passing mahasiswa. Berdasarkan hasil uji hipotesis model latihan passing sepakbola telah memberikan pengaruh yang berarti terhadap kemampuan passing dari mahasiswa, sehingga dapat ditarik kesimpulan bahwa model latihan passing ini dapat digunakan kepada mahasiswa atau pelajar yang baru berlatih passing sepakbola.
\end{abstract}

Kata kunci: Pengembangan, Model, Passing

\section{Abstract}

The number of weaknesses in football matches, especially weaknesses in terms of passing a ball, is one of the keys to the failure of a team in a match. This research aims to develop a form of passing football practice. This study uses a development research approach with a sample of UNIB PJKR students. The data analysis technique used is the t-test with calculations through SPSS version 16. The t-test results showed that the coefficient of significance was 0,000, this coefficient was compared with the significance level of 0.05 . Based on the comparison it turns out that the coefficient of significance is smaller than the significance level of 0.05, so it can be concluded that the passing training program has an effect on the ability of passing students. Based on the results of the hypothesis testing soccer passing training model has a significant influence on the ability of passing from students, so it can be concluded that this passing training model can be used for students or students who are just practicing football passing.

Keywords: Development, Model, Passing

corresponding author: dianpujianto@unib.ac.id

Artikel Info:

Submitted: 04/03/2020

Revised : 25/03/2020

Accepted : 15/04/2020

Published: 20/05/2020

Journal Coaching Education Sports is licensed under a Creatives Commons Attribution 4.0 International License.

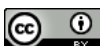




\section{A. Pendahuluan}

Lulusan program studi pendidikan jasmani, kesehatan, dan rekreasi (PJKR) diprogram untuk memiliki kompetensi dalam mendidik peserta didik dan mengajarkan keterampilan baru kepada peserta didiknya (Maulana et al., 2018). Mahasiswa PJKR diberi bekal untuk dapat mendidik peserta didik melalui aktifitas jasmani, seperti olahraga, bermain, aktifitas rekreasi, dalam proses perkuliahan mahasiswa diberikan bekal berbagai keterampilan olahraga dan mahasiswa wajib memiliki salah satu keahlian dalam bidang olahraga yang harus dikuasai (Putranto \& Andriadi, 2019). Keahlian dalam bidang olahraga yang dimaksud adalah mahasiswa memiliki keterampilan melatih atau membuat program latihan atau memiliki sertifikat perwasitan daerah (Nasution \& Suharjana, 2015).

Ketiga keterampilan di atas minimal satu harus dikuasai oleh mahasiswa, sehingga setelah lulus mahasiswa benarbenar memiliki kompetensi. Berdasarkan hal ini maka program studi memberikan kewenangan pada dosen pengampu mata kuliah untuk memberikan kesempatan pada mahasiswa mengembangkan potensinya. Mata kuliah sepakbola merupakan salah satu mata kuliah wajib, di dalam mata kuliah ini mahasiswa diberikan keterampilan bermain bola melalui penguasaan teknik-teknik dasar bermain sepakbola, dan diberikan keterampilan memimpin pertandingan sekaligus bagaimana cara-cara mengajar sepakbola kepada calon peserta didik.

Pada proses perkuliahan yang telah berlangsung pada semester sebelumnya terdapat beberapa mahasiswa yang memerlukan remidi dalam beberapa teknik yang ada dlam sepakbola. Berdasarkan hal ini maka dosen pengampu mata kuliah mengidentifikasi beberapa teknik sepakbola masih sering harus diremidi oleh mahasiswa, yaitu (1) Passing atau mengoper, (2) menembak, dan (3) menyundul (Hargreaves \& Pringle, 2019). Teknik mengoper berada diurutan pertama yang sering diremidi oleh mahasiswa, padahal teknik ini adalah teknik dasar yang harus dikuasai oleh seorang pesepakbola, ketika pesepakbola mengoper saja tidak berhasil dengan baik, maka permainan tim menjadi kacau dan mudah direbut atau dikuasai oleh lawan (Qader et al., 2017). Berdasarkan permasalahan ini maka dosen pengampu akan merubah model latihan mengoper yang sudah untuk 
merubah kelemahan-kelemahan yang ada pada model latihan sebelumnya.

Model latihan yang akan diprogramkan adalah sebuah model latihan mengoper dengan memanfaatkan mahasiswa sebagai rintangan dan dengan bermain (Pasaribu, 2016). Pada model sebelumnya latihan hanya menggunakan cone sebagai rintangan dan dilakukan dengan cara berulangulang. Pada cara sebelumnya ternyata kegiatannya berjalan dengan cukup baik akan tetapi hasil dari kegiatan pembelajaran masih belum memuaskan, sehingga perlu adanya perbaikan untuk membuat model latihan yang lebih menyenangkan lagi yang kedepannya dapat membuat hasil belajar mahasiswa menjadi lebih baik lagi (Vaz et al., 2019). Berdasarkan permasalah yang ada dalam latar belakang masalah maka rumusan masalah dalam penelitian ini adalah bagaimana program latihan passing atau mengoper yang mampu memberikan hasil belajar passing mahasiswa menjadi baik?

\section{B. Metode Penelitian}

a) Tempat dan Waktu Penelitian

Penelitian dilakukan di Prodi PJKR FKIP UNIB pada cabang sepakbola.
Tempat yang digunakan untuk uji coba kelompok kecil adalah di Lapangan UNIB sesuai dengan jam latihan. Untuk uji awal model latihan dilakukan kepada seluruh Mahasiswa PJKR FKIP UNIB yang menjadi anggota PS FKIP yang terdiri dari 10 pemain. Sedangkan untuk uji coba utama menggunakan subjek seluruh mahasiswa PJK FKIP yang mengikuti perkuliahan sepakbola sebanyak 60 pemain.

b) Karakteristik Model yang Dikembangkan

Dalam penelitian ini, pertama dilakukan adalah menggali informasi staf pengajar sepakbola PJKR FKIP, mengenai pandangan terhadap pelaksanaan latihan, model latihan dan juga literatur yang digunakan saat menyiapkan berbagai variasi latihan, serta fasilitas dan alat-alat yang dimiliki oleh program studi PJKR FKIP untuk mendukung pelaksanaan pelatihan. Disamping itu juga peneliti melakukan analisis tentang model latihan yang digunakan selama ini. Berdasarkan konten ini kemudian peneliti akan menganalisis dan merancang model latihan passing yang bisa dianalogikan dengan konsep latihan agar dapat diterapkan dalam proses latihan di prodi PJKR FKIP di cabor sepakbola. 
Selanjutnya hasil analisistersebut akan dikolaborasikan dengan model yang di kembangkan saat ini. Konten hasil analisis tersebut dipergunakan sebagai acuan dalam mengembangkan model latihan passing.

Rancangan model latihan passing yang akan dikembangkan dibagi menjadi dua tahap yaitu sebagai berikut:

1. Draf model latihan passing tahap I

a. Teknik dasar passing kaki bagian dalam

Petunujuk Pelaksanaan; Bola 1 meter di luar kotak pinalti, jarak pemain dengan bola 2-3 meter. Setelah mendengar peluit, pemain langsung melakukan passing ke gawang menggunakan teknik kaki bagian dalam.Lakukan tendangan dengan perlahan-lahan sampai pemain menguasai tenik dengan benar.

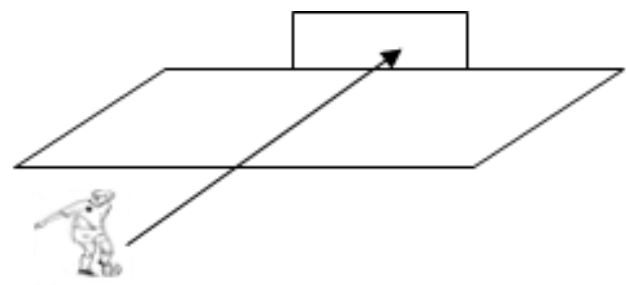

Gambar 1. Passing kaki bagian. Dalam

b. Teknik dasar passing kaki bagian luar

Petunujuk pelaksanaan; Bola 1 meter di luar kotak pinalti, jarak pemain dengan bola 2-3 meter. Setelah mendengar peluit, pemain mengoper bola dengan kaki bagian luar. Dengan kaki kanan atau kiri menggunakan secara bergantian. Lakukan tendangan dengan perlahan-lahan sampai pemain menguasai tenik dengan benar.

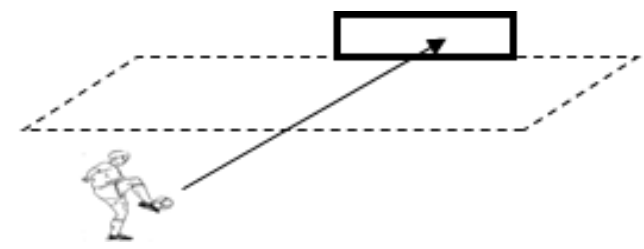

Gambar 2. Passing kaki bagian luar

c. Teknik dasar passing dengan punggung kaki

Petunujuk pelaksanaan; Bola 1 meter di luar kotak pinalti, jarak pemain dengan bola 2-3 meter. Setelah mendengar peluit, pemain mengoper dengan punggung kaki. Dengan kaki kanan atau kiri menggunakan secara bergantian. Lakukan tendangan dengan perlahan-lahan sampai pemain menguasai tenik dengan benar.

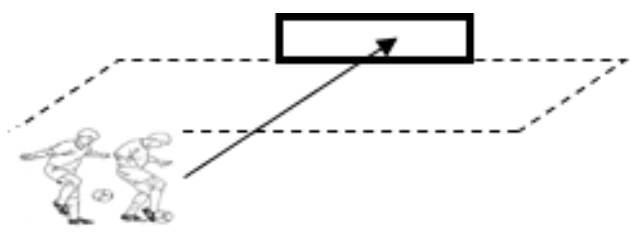

Gambar 3. Passing dengan punggung kaki

d. Teknik dasar passing kaki bagian dalam dengan bola pantul Petunujuk pelaksanaan; Bola 1 meter di luar kotak pinalti, jarak pemain dengan bola 2-3 meter. Setelah 
mendengar peluit, pemain melambungkan bola sendiri, sebelum bola menyentuh tanah pemain langsung melakukan passing ke teman menggunakan teknik kaki bagian dalam.

Dengan kaki kanan atau kiri menggunakan secara bergantian. Lakukan tendangan dengan perlahanlahan sampai pemain menguasai tenik dengan benar.

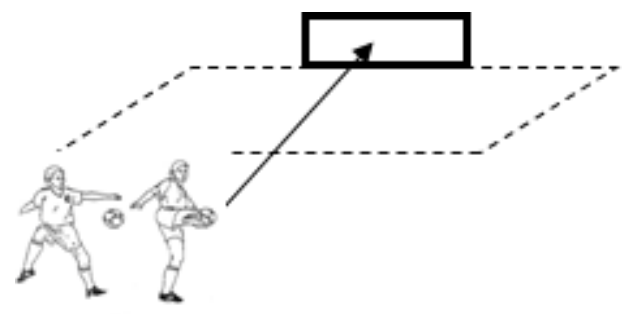

Gambar 4. Passing kaki bagian dalam dengan bola pantul

e. Teknik dasar passing kaki bagian luar bola pantuk

Petunjuk pelaksanaan; Bola 1 meter di luar kotak pinalti, jarak pemain dengan bola 2-3 meter. Setelah mendengar peluit, pemain melambungkan bola sendiri, sebelum bola menyentuh tanah pemain langsung melakukan passing ke teman menggunakan teknik kaki bagian luar.

Dengan kaki kanan atau kiri menggunakan secara bergantian. Lakukan tendangan dengan perlahanlahan sampai pemain menguasai tenikdengan benar.

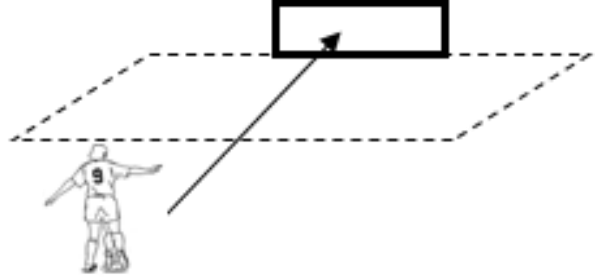

Gambar 5. Passing kaki bagian luar bola pantul

2. Draf model latihan passing Tahap II

a. Teknik lanjutan kaki bagian dalam

Pelatih membawa bola berada di depan gawang diluar kotak pinalti dengan menghadap ke gawang. 2 Pemain berada di depan gawang di luar kotak pinalti dengan membelakangi gawang. 1 pemain menjadi penyerang 1 pemain menjadi pemain bertahan. Posisi pemain bertahan tepat di belakang pemain menyerang. Pelatih mensevis bola ke samping kanan/kiri pemain. Pemain menyerang langsung balik badan dan melakukan passing menggunakan teknik kaki bagian dalam ke sasaran yang telah di tetapkan.

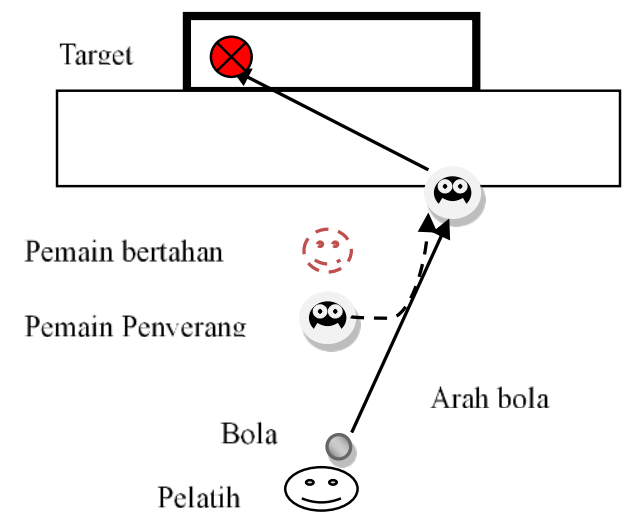

Gambar 6: Intermediet Pass versi 1 Teknik lanjutan kaki bagian dalam 


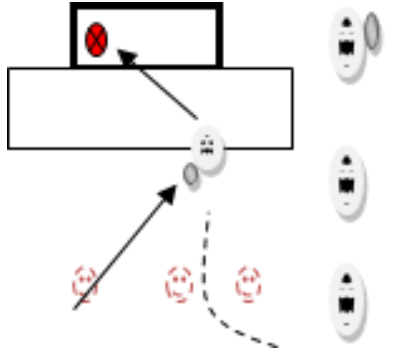

$\theta$

Gambar 7. Intermediet passing versi 2

a) Pendekatan dan Metode Penelitian

Pendekatan dan metode yang digunakan dalam penelitian ini adalah metode penelitian dan pengembangan (research and development/R\&D), dengan desain pengembangan yang dipilih adalah merujuk pada pengembangan yang dikemukakan oleh Borg and Gall yang terdiri dari 10 tahap. Langkah-langkah pengembangan dalam penelitian ini yaitu:

\section{Penelitian pendahuluan}

Sesuai dengan model pengembangan borg and gall, maka penelitian pendahuluan dalam pengembangan model latihan passing ini difokuskan pada analisis awal/identifikasi mengenai masalah serta kebutuhan yang diperlukan dalam latihan yang tengah berjalan .

2. Perencanaan pengembangan model

Perhatian dalam perencanaan pengembangan model difokuskan pada proses perumusan/penyusunan rancangan model, berupa garis besar komponen model latihan passing seperti: teknik, fase latihan, fase latihan teknik skill, materi latihan dan alat penunjang latihan.

3. Validasi, Evaluasi, Dan Revisi Model

a. Proses dan hasil uji coba atau validasi dimaksudkan untuk memperoleh masukan, saran dan penilaian melalui telaah pakar/panel/ expert judgement terhadap model yang dikembangkan. Pada tahap uji coba utama ini atau main field testing menggunakan subjek 35 pemain dikumpulkan melalui instrument test ketrampilan passing. Berikut ini tes untuk mengetahui hasil passing yang akan digunakan dalam penelitian ini menurut Nurhasan (2007). Sedangkan untuk mengukur kemampuan teknik passing menggunakan lembar observasi menurut Widiastuti (2015). Data hasil pre-test dan post-test keterampilan passing sepakbola terhadap kelompok eksperimen dan kelompok kontrol dianalisis menggunakan SPSS 17.0 for windows dengan analisis sebagai berikut menurut sugiyono (Sugiyono, 2009).

Uji Prasyarat Analisis

Berikut ini langkah-langkah yang dilakukan peneliti saat uji prasyarat 
analisis:

1) Uji normalitas dalam penelitian ini digunakan untuk untuk menguji data yang diperoleh berdistribusi normal, dilakukan menggunakan uji Kolmogorove-Semirnov dengan taraf signifikan 5\%.

2) Uji Homogenitas dalam penelitian ini digunakan untuk menguji data yang diperoleh apakah homogen atau tidak. Menggunakan uji levenes's test.

b. Uji Statistik Hipotesis

Untuk mengetahui perbedaan pengaruh perlakuan pada variabel terikat hasil passing sebelum dan setelah perlakuan setiap kelompok digunakan Paired t-test.

4. Ujicoba operasional (operational field testing)

Tahap ujicoba operasional model latihan passing sepakbola dilakukan uji coba melibatkan 2-4 klub sepakbola dengan melibatkan 10-50 subjek. Tujuan ujicoba pada tahap ini adalah untuk menentukan apakah produk yang dikembangkan sepenuhnya siap digunakan di klub sepakbola meski tanpa kehadiran peneliti. Data dikumpulkan melalui observasi, wawancara, dan angket. Berikut ini teknik yang digunakan untuk menggupulkan data pada tahap uji coba operasional (operational field testing).

a. Pengumpulan Data

Teknik pengumpulan data pada tahap ini menggunakan langkah sebagai berikut:

1) Catatan lapangan untuk mencatat hasil observasi, selama berlangsungnya uji coba

2) Wawancara kepada pelatih klub yang menjadi subjek penelitian terkait model yang yang dikembangkan

3) Angket sebagai instrumen uji coba untuk para ahli, pelatih, ahli kepelatihan dan mantan atlet sepakbola dan pemain berupa pertanyaan dengan mengacu pedoman sebagai berikut:

b. Analisis Data

Data yang tekumpul saat analisis kebutuhan, validasi ahli, uji coba awal, dan uji operasional maupun hasil observasi dan saran serta masukan dianalisis saat pengumpulan data berlangsung dan setelah selesai pengumpulan data, dengan cara merangkum data guna memilih hal-hal pokok dan penting, kemudian menyajikan data agar mudah dipahami sesuai apa yang terjadi serta merencanakan kerja selanjutnya. Sedangkan data kuantitatif hasil penyebaran angket dianalisis dengan 
menggunakan teknik analisis deskriptif dengan persentase (Suharsimi, 2009). Kerja berikutnya penarikan kesimpulan dan verifikasi yang merupakan temuan baru berupa deskriptif (Sugiyono, 2009). Mengambil kesimpulan umum pada model latihan passing sepakbola secara keseluruhan hasil validasi subyek uji coba, maka digunakan analisis deskriftif kuantitatif dengan kriteria yang telah ditetapkan.

Tujuan ujicoba pada tahap ini adalah untuk menentukan apakah produk yang dikembangkan sepenuhnya siap digunakan di klub sepakbola. Hasil uji coba ini dilakukan analisis hasil uji operasional yan akan dijadikan konsep panduan dan konsep naskah (storyboard script). Konsep naskah yang telah disusun, dikonsultasikan dengan ahli media untuk digunakan sebagai persiapan pembuatan video. Sedangkan angket, serta catatan lapangan sebagai feedback (umpan balik) yang bisa digunakan sebagai perbaikan dan penyempurnaan model latihan berikutnya sampai ke tahap optimalisasi model siap pakai. Bertitik tolak dari hasil revisi produk ketiga (III) dibuat produk buku panduan dan video model latihan passing sepakbola. Setelah produk ini selesai, divalidasi oleh ahli. Para ahli tersebut memberikan saran, masukan berupa penilaian, komentar melalui instrument angket setelah mengamati pemutaran video hasil pengembangan model latihan passing sepakbola. Hasil validasi ahli tersebut, digunakan sebagai melakukan revisi produk akhir dan selanjutnya diperoleh produk akhir yang efektif. Hasil produk akhir ini berupa buku panduan model latihan passing untuk Prodi PJKR FKIP UNIB.

\section{Hasil dan Pembahasan}

\section{a) Hasil Penelitian}

1. Data hasil uji coba

Berdasarkan hasil uji coba kelompok kecil yang telah dilaksanakan dapat diperoleh data sebagai berikut;

Tabel 1. Data uji coba kelompok kecil.

\begin{tabular}{ccc}
\hline No & Tes Awal & Tes Akhir \\
\hline 1 & 3.0 & 10.0 \\
\hline 2 & 2.0 & 9.0 \\
\hline 3 & 4.0 & 14.0 \\
\hline 4 & 5.0 & 14.0 \\
\hline 5 & 6.0 & 16.0 \\
\hline 6 & 5.0 & 17.0 \\
\hline 7 & 5.0 & 14.0 \\
\hline 8 & 7.0 & 14.0 \\
\hline 9 & 9.0 & 16.0 \\
\hline 10 & 4.0 & 12.0 \\
\hline $\bar{X}$ & 5,0 & 13,6 \\
\hline
\end{tabular}

Dari tabel di atas dapat diketahui bahwa rata-rata tes awal adalah 5 dan rata-rata tes akhir adalah 13,6. Berdasarkan angka rata-rata ini maka dapat dilihat bahwa ada peningkatan 
kemampuan passing setelah diberikan perlakuan pada kelompok kecil. Untuk mengetahui apakah ada peningkatan secara signifikan atau tidak maka akan di uji dengan uji perbedaan dengan uji t. Sebelum uji t dilakukan maka akan di uji normalitas dan uji homogenitas data sebagai uji prasyaratnya.

2. Uji normalitas data

Uji normalitas data menggunakan program Spss versi 16. Uji normalitas data menggunakan uji KolmogorovSmirnov dengan koreksi uji lilliefors. Berdasarkan hasil perhitungan uji normalitas data diperoleh signifikasi data tes awal 0.200 dan data tes akhir 0,051 . Hasil ini dibandingkan dengan tarah signifikasi sebeesar 0,05 , dan ternyata kedua kelompok data memiliki signifikasi lebih besar dari taraf signifikasi yang ada,sehingga dapat disimpulkan bahwa kedua data normal.

\section{Uji Homogenitas}

Uji homogenitas data menggunakan program Spss versi 16. Uji homogenitas data menggunakan uji $\mathrm{F}$, yaitu membagi varians terbesar dengan varians terkecil dari kedua kelompok. Berdasarkan hasil uji homogenitas diperoleh harga signifikasi dari uji F sebesar 0,402, harga ini kemudian dibandingkan dengan harga taraf signifikasi sebesar
0,05 . Ternyata harga signifikasi lebih besar dari harga taraf signifikasi sehingga dapat ditarik kesimpulan bahwa kedua populasi homogen. Dengan demikian uji prasyarat telah memenuhi untuk dilakukan uji hipotesis dengan menggunakan uji t. Uji t ini untuk mengetahui apakah ada perbedaan antara sebelum perlekuan dengan sesudah perlakuan.

\section{Uji Hipotesis}

Berdasarkan hasil uji-t diperoleh harga signifikasi uji t sebesar 0,000, harga ini kemudian dibandingkan dengan taraf signifikasi sebesar 0,05. Ternyata harga signifikasi lebih kecil dari harga taraf signifikasi, sehigga dapat disimpulkan bahwa ada perbedaan antara kemampuan passing sebelum diberi perlakuan dengan setelah diberikan perlakuan. Dengan demikian dapat ditarik sebuah kesimpulah bahwa model latihan passing yang telah diberikan memberikan hasil yang nyata terhadap kemampuan passing pemain sepakbola pada tingkat awal

\section{b) Pembahasan}

Berdasarkan hasil uji hipotesis dapat dibuktikan bahwa model latihan passing yang telah disusun tim peneliti telah memberikan pengaruh yang berarti terhadap kemampuan passing dari para 
sampel penelitian. Dalam permainan sepakbola passing merupakan salah satu unsur pokok dalam permainan, karena tanpa passing yang tepat maka kerjasama tim tidak akan berjalan dengan baik. Ketika passing telah tepat maka permainan sebuah tim sepakbola akan tersaji dengan baik dan dapat dinikmati. Model latihan passing yang disusun oleh tim peneliti merupakan model latihan passing dengan memanfaatkan media yang ada. Sehingga dapat digunakan oleh para guru pendidikan jasmani yang memiliki kekurangan dalam fasilitas atau sarana prasarana dalam mengajar permainan sepakbola.

Bentuk latihan yang diberikan adalah latihan dari yang mudah menuju ke sukar, dengan menggunakan rintangan teman yang ada, dan sasaran juga dengan bagian tubuh dari teman. Dari hasil pengamatan ternyata sampel tampak lebih semangat ketika berlatih, ini mengindikasikan bahwa proses latihan telah mendapatkan tempat yang sesuai dengan keinginan para sampel. Ketika pembelajar antusias untuk berlatih maka dia akan terus mengulang dan mengulang bentuk latihan yang diberikan. Keterampilan gerak akan meningkat apabila dilatihkan pada semua individu. Baik itu keterampilan yang berkaitan dengan teknik olahraga maupun kemampuan fisik. Model latihan passing ini telah terbukti mampu meningkatkan kemampuan passing mahasiswa. Penggunaan peralatan minimalis ternyata tidak menjadi halangan dalam latihan passing, sehingga modellatihan ini dirasa akan tepat digunakan dalam pembelajarn passing terutama bagi sekolah yang memiliki fasilitas yang kurang memadai.

\section{Kesimpulan}

Berdasarkan hasil uji hipotesis model latihan passing sepakbola telah memberikan pengaruh yang berarti terhadap kemampuan passing dari mahasiswa, sehingga dapat ditarik kesimpulan bahwa model latihan passing ini dapat digunakan kepada mahasiswa atau pelajar yang baru berlatih passing sepakbola. Berdasarkan kesimpulan penelitian yang telah diuraikan, maka dapat diketengahkan saran-saran sebagai berikut: Dalam pembelajaran pendidikan jasmani seorang guru harus kreatif dalam mengatasi permasalahan minimnya sarana prasarana kegiatan belajar. Program latihan passing ini merupakan pengembangan dari program latihan passing yang sudah ada, sehingga bagi 
guru yang akan mengembangkan lebih lanjut dapat merujuk kepada program latihan ini.

\section{Daftar pustaka}

Hargreaves, J., \& Pringle, A. (2019). "Football is pure enjoyment": An exploration of the behaviour change processes which facilitate engagement in football for people with mental health problems. Mental Health and Physical Activity, 16(June 2018), 19-30. https://doi.org/10.1016/j.mhpa.201 9.02.002

Maulana, A., Azhari, A., \& Darmawan, A. (2018). Pengembangan Model Latihan Renang Berbasis Mobile Learning Untuk Mahasiswa Pendidikan Jasmani, , Bravo's Jurnal, 6(4), 150-155. http://www.ejournal.stkipjb.ac.id/i ndex.php/penjas/article/view/973

Nasution, I. E., \& Suharjana, S. (2015). Pengembangan Model Latihan Sepak Bola Berbasis Kelincahan Dengan Pendekatan Bermain. Jurnal Keolahragaan, 3(2), 178193.

https://doi.org/10.21831/jk.v3i2.62 41

Pasaribu, A. M. N. (2016). Pengaruh
Gaya Menagajar dan Motivasi Belajar Passing Bawah dalam Permainan Bola Voli pada Siswa SMP Kelas VIII. Jurnal SPORTIF : Jurnal Penelitian Pembelajaran, 2(2), 85-97. https://doi.org/https://doi.org/10.29 407/js_unpgri.v2i2.510

Putranto, D., \& Andriadi, A. (2019). Pengembangan Model Latihan Passing ADE Sepakbola. SPORTIVE: Journal Of Physical Education, Sport and Recreation, 2(2), 73. https://doi.org/10.26858/sportive.v $2 \mathrm{i} 2.9514$

Qader, M. A., Zaidan, B. B., Zaidan, A. A., Ali, S. K., Kamaluddin, M. A., \& Radzi, W. B. (2017). A methodology for football players selection problem based on multimeasurements criteria analysis. Measurement: Journal of the International Measurement Confederation, $111, \quad 38-50$. https://doi.org/10.1016/j.measurem ent.2017.07.024

Vaz, M. S., Ribeiro, Y. S., Pinheiro, E. S., \& Del Vecchio, F. B. (2019). Psychophysiological profile and prediction equations for technical performance of football players. 
Revista Brasileira de Ciencias Do

Esporte, 41(2), 215-221.

https://doi.org/10.1016/j.rbce.2018.

04.009

Arikunto, A. (2009). Statistik untuk Penelitian. Bandung : Alfabeta.

Borg, W.R., \& Gall, M.D. (1983).

Educational Research. USA : Human Kinetics.

Emral. (2013). Pengembangan Model

Latihan Keterampilan Teknik Dasar Bermain Sepakbola Siswa SSB PSTS Tobing Padang. Jakarta : PPs UNJ, Disertasi.

Gatz, G. (2009). Complete Conditioning fot Soccer. USA : Human Kinetics.

Hariyoko. (2012). Pengembangan Model Pembelajaran Keterampilan Dasar Sepakbola Peserta Ekstrakurikuler Sepakbola SMP $N$ di Kota Malang. Jakarta : PPs UNJ, Disertasi.

Cook, M. (2011). 101 Drills Sepakbola untuk Pemain Muda, Usia 12 16 Tahun. Jakarta : Indeks.

Maksum, A. (2012). Metodologi Penelitian dalam Olahraga. Surabaya: Unesa University Press.

Nurhasan. (2007). Pengantar Tes dan
Pengukuran, Kegunaan Tes dan Pengukuran, Kriteria Tes. Jakarta : Kurnia.

Putra, N. (2012). Research and Development. Jakarta : Rajawali Press. Sukmadinata. (2015). Metode Penelitian Pendidikan. Jakarta : PT Remaja Rosdakarya. Widiastuti. (2009). Tes dan Pengukuran Olahraga. Jakarta : Raja Grafindo 
